\title{
Environmental Geochemistry of Igarra Marble Mining District, Southwestern Nigeria
}

\author{
Mohammed Suleiman Chaanda, Ovie Izeze, Igbinosa Temple Osaze \\ Department of Earth Sciences, Federal University of Petroleum Resources, Effurun, Nigeria \\ Email: chaandamohammed@gmail.com
}

How to cite this paper: Chaanda, M.S. Izeze, O. and Osaze, I.T. (2019) Environmental Geochemistry of Igarra Marble Mining District, Southwestern Nigeria. Journal of Environmental Protection, 10, 722-737.

https://doi.org/10.4236/jep.2019.106043

Received: February 16, 2019

Accepted: June 14, 2019

Published: June 17, 2019

Copyright $\odot 2019$ by author(s) and Scientific Research Publishing Inc. This work is licensed under the Creative Commons Attribution International License (CC BY 4.0).

http://creativecommons.org/licenses/by/4.0/

\begin{abstract}
The determination of the impacts of marble mining on the environment in Igarra was carried out via the analysis of soil and water samples as geological medium. Seven soil samples, ten water samples and five rock samples were collected. The samples collected were subjected to petrographic and geochemical analysis. The mean concentration of metals in soil from Ekpeshi were Cd (3.254 mg/kg), Co (786.554 mg/kg), Cu (12.911 mg/kg), Ni (18.942 $\mathrm{mg} / \mathrm{kg}), \mathrm{Pb}(5.5 \mathrm{mg} / \mathrm{kg})$, and $\mathrm{Zn}(28.457 \mathrm{mg} / \mathrm{kg})$ while the concentrations of the water samples collected from streams, taps and wells were $\mathrm{Cd}(0.116$ $\mathrm{mg} / \mathrm{kg}), \mathrm{Co}(15.225 \mathrm{mg} / \mathrm{kg}), \mathrm{Cu}(0.542 \mathrm{mg} / \mathrm{kg}), \mathrm{Ni}(0.276 \mathrm{mg} / \mathrm{kg}), \mathrm{Pb}(0.486$ $\mathrm{mg} / \mathrm{kg})$, and $\mathrm{Zn}(0.742 \mathrm{mg} / \mathrm{kg})$. Lead $(\mathrm{Pb})$ showed high concentration of $(0.486 \mathrm{mg} / \mathrm{kg}), \mathrm{Ni}(0.276 \mathrm{mg} / \mathrm{kg})$ and $\mathrm{Cd}(0.116 \mathrm{mg} / \mathrm{kg})$ as against acceptable limits of $0.01 \mathrm{mg} / \mathrm{l}, 0.02 \mathrm{mg} / \mathrm{l}$ (NIS) and $0.07 \mathrm{mg} / \mathrm{l}$ (WHO) $0.003 \mathrm{mg} / \mathrm{l} \mathrm{respec-}$ tively, while in soil it showed high concentration of Cd $(3.254 \mathrm{mg} / \mathrm{kg}) \mathrm{com}$ pared to the acceptable limit of $0.8 \mathrm{mg} / \mathrm{kg}$ set by the Dutch Standard limit for soil. Lead, Nickel and Cadmium are found to be in high concentration in both surface and underground water, and this calls for treating water in the study area before it's used as drinking water via drilling water boreholes by the mining and processing companies operating in the area as a form of corporate social responsibility. Also, the provisions in the mining act should holistically be implemented to safe life and health of the populace of the immediately surroundings.
\end{abstract}

\section{Keywords}

Marble, Mining, Heavy Metals, Portable Drinking Water, Soil Value, Igarra

\section{Introduction}

Marbles are generally metamorphic derivatives of sedimentary carbonates. They 
have been known to be relatively impermeable during metamorphism [1]. A review of the economic utilization of carbonates therefore to some extent takes into consideration aspects of the mineralogy, physical and chemical properties of the marble deposits [2]. Igarra area in Edo State, Nigeria, is endowed with large marble deposit associated with biotite schist and gneiss. The marble deposits with the above phrase are been exploited and mined for many purposes. The quest for exploitation of valuable mineral resources in the earth to satisfy human wants has given rise to technological development in mining industry. This demonstrate the best mining methods that fit the geometry and the structural orientation of the deposit which is to be mined within the limits allowable safety standard, technology, and economics, with the lowest cost and return of maximum profit [3]. Since the only practical way to extract minerals for industrial application is through mining; the impact of mining cannot be avoided.

Abundance of marble for industrial purposes has made Igarra and Ekpeshi an ideal means source of raw materials to many developers in these areas and elsewhere. The negative effect on the environment due to activities involved in harnessing the minerals cannot be over emphasized. The environment has three components, namely, the sum of external conditions in which organisms exist; the organisms themselves including the floral and faunal community; and the physical surroundings such as landforms. All these three aspects, which include various entities such as atmosphere, hydrosphere, biosphere, land, vegetation, animals including human, landscape and geomorphologic features, archeological heritage and so on, are adversely affected in one way or the other during mineral resource extraction [4].

Varying degrees of pollution of air, water and land occur during mineral extraction depending on the stage and scale of activities attained. While only minor pollution if at all exist are observed during mineral exploration, more intense air and water pollution emanates from the exploitation stage, particularly if carried out on a large scale [5]. Vegetation in form of natural forest or Man-made plantation is usually the first casualty to suffer total or partial destruction or degradation during the exploration and exploitation of minerals in a mining site or district.

A prominent negative effect of mining is the destruction of the natural landscape, creating open pits in the ground and generating heaps of rock wastes that cannot be easily disposed of [4]. Other forms of impacts that could occur because of extraction activities, include noise and vibration due to blasting and the operation of equipment. Quarrying and mineral processing industries are the major cause of environmental pollution in the Igarra marble mining district.

\section{Study Area}

The study areas lie between longitudes $6^{\circ} 10^{\prime} 00^{\prime \prime} \mathrm{E}$ and $6^{\circ} 12^{\prime} 00^{\prime \prime} \mathrm{E}$, and latitudes $7^{\circ} 11^{\prime} 00^{\prime \prime} \mathrm{N}$ and $7^{\circ} 6^{\prime} 00^{\prime \prime} \mathrm{N}$ Ekpeshi, and longitudes $6^{\circ} 6^{\prime} 00^{\prime \prime} \mathrm{E}$ and $6^{\circ} 7^{\prime} 30^{\prime \prime} \mathrm{E}$, and latitudes $7^{\circ} 18^{\prime} 00^{\prime \prime} \mathrm{N}$ and $7^{\circ} 16^{\prime} 00^{\prime \prime} \mathrm{N}$ Igarra (Figure 1). The study area falls under Igarra town with an area coverage of about $3000 \mathrm{~km}^{2}$, and Ekpeshi, a village 
along the Igarra-Auchi Road in Akoko Edo Local Government, Edo State, where most of the mines and marble milling plants are located.

The region has a warm tropical climate with little or no variation depending on the amount of rainfall. The average temperature is between $24^{\circ} \mathrm{C}$ and $28^{\circ} \mathrm{C}$ [6]. Humidity is constantly high, and the area has a tropical climate that experiences both rainy and dry seasons. The rainy season usually begins with southwest winds from April to October with the peak period in July and August every year. The total amount of precipitation ranges from $1270 \mathrm{~mm}$ to $1790 \mathrm{~mm}$ [7]. Furthermore, dry season begins from November to March, which is marked by the northeast, cold, and dry harmattan wind usually blown from the Sahara

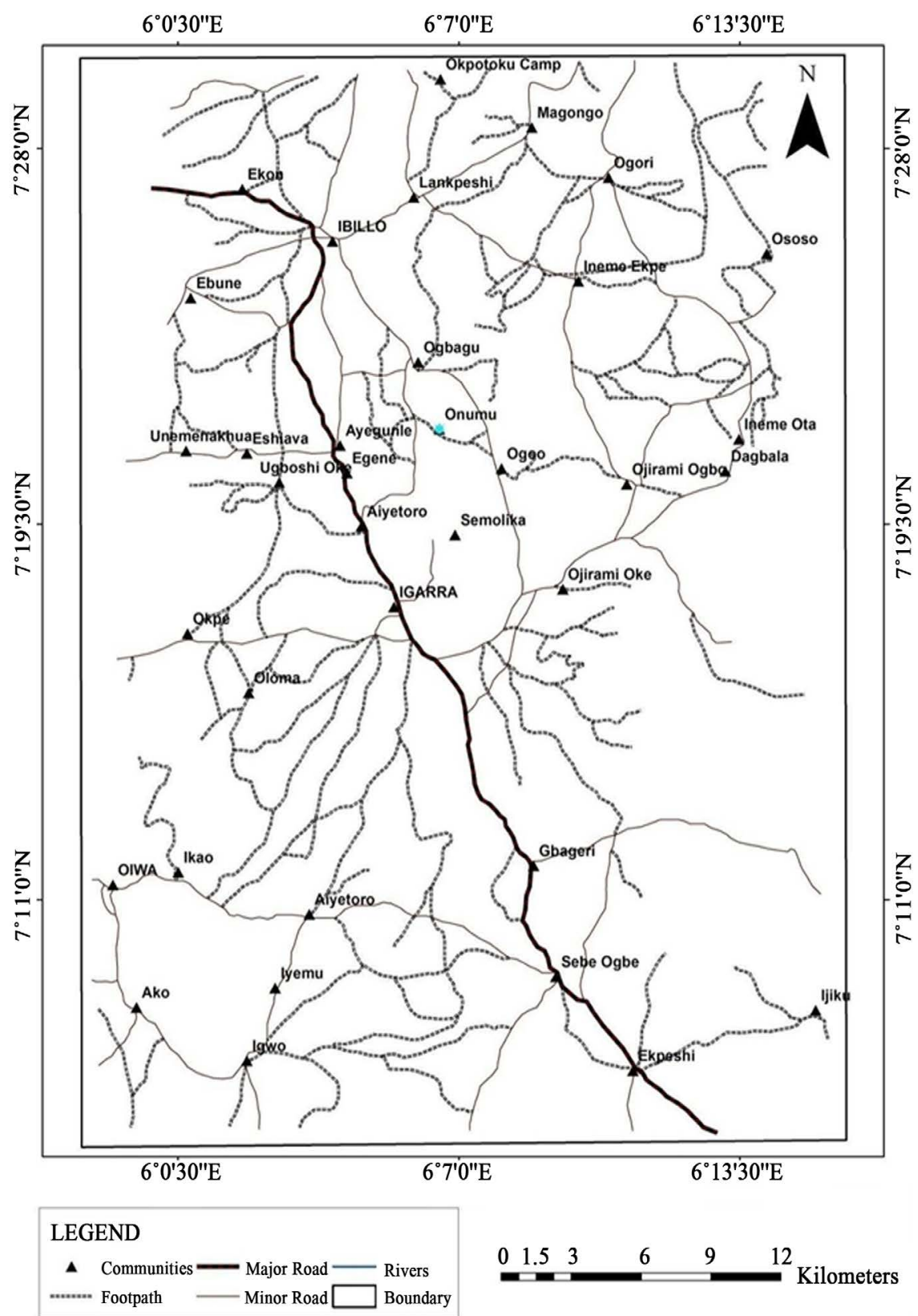

Figure 1. Map of the study area. 
Desert [8]. The study area lies in the transition between tropical rain forest and savannah belt (grassland) [8]. The topography of the area presents the general configuration of the land surface (geomorphology). It is characterized by gentle, steep, and rugged topography with high relief. It featured mainly basement complex rocks with some of these rocks exposed as high ridges and valleys because of tectonic activities and erosion with the rocks having an important effect on the soil of the area [9].

The study are forms part of the Igarra Schist belt of Southwestern Nigeria. Rocks in this area are mainly Schist which consist of a highly deformed metamorphic suite and had been intruded by igneous plutons of Pan-African age. The rocks comprise of meta-sedimentary rocks which include schist, amphibolite, calc-silicate gneiss and marble which have been subjected to polyphase deformation and have subsequently been intruded by post-tectonic granitic rocks of Pan-African (600 $\pm 150 \mathrm{Ma}$ ) age [10] (Figure 2).

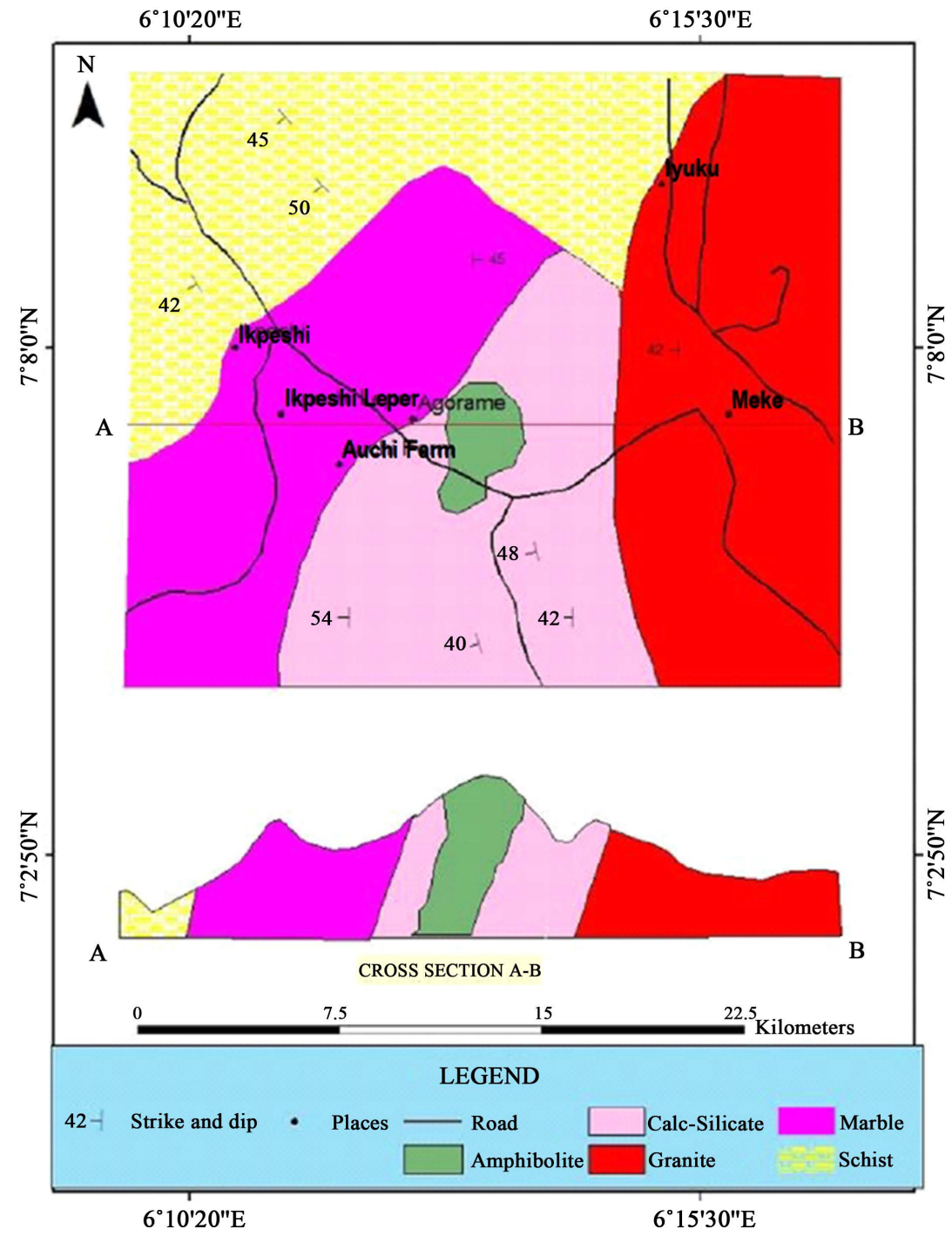

Figure 2. Geologic map of the Study Area (Source: modified from [10]). 
The geologic structure of the area contributes to defining the drainage system. The nature of the drainage pattern is mainly Dendritic, Radial and Trellis as a factor of the relief, primarily in response to the kinds of rocks on which the streams developed from or the structural pattern of its faults and folds. Most of the river channels such as river Ekpesi, run from the North-Eastern to the South-Western of the study area. The streams are seasonal, flowing during period of heavy rainfall and moderately or completely dry during the dry season.

\section{Methodology}

The research was carried out in three phases: field mapping and collection of samples, laboratory analysis and writing/interpretation of results. The physic-chemical parameters in the soil and water samples analyzed are temperature, $\mathrm{pH}$, conductivity, total dissolved solid, copper, nickel, zinc, lead, cobalt, and cadmium. The rock samples were subjected to AAS analysis. All data used in this work was a product of the field mapping undertaking in Ekpeshi and Igarra district and the laboratory analysis of the samples.

\subsection{Method of Samples Collection and Analysis}

The basic materials and equipment used in carrying out this study were: one liter of plastic container, polythene bags, masking tape, marker, camera, writing pad, GPS, $\mathrm{pH}$ meter, and TDS/EC/temperature meter. All the sampling bottles were washed with sample water before sampling to reduce contamination. A total of twenty-two (22) samples were collected at the field. Seven (7) soil samples were taken from quarry sites and processing factories specifically (at a depth of $0.3 \mathrm{~m}$ - $0.45 \mathrm{~m}$ on the average), ten (10) water samples in which four (4) samples collected from streams, three (3) water samples collected from tap, and three (3) water samples collected from hand-dug well. Out of the ten (10) water samples, seven (7) are collected at Ikpeshi, while 3 are collected at Igarra. Both the water and soil samples were collected as replicate samples in dry and wet seasons (April and June 2018). Five (5) rock samples were collected at three (3) marble quarries. The samples were marked and labeled with the source of water, sampling location and date of water sample collection. The $\mathrm{pH}$ of the water samples, the conductivity, temperature and TDS were determined in-situ during sample collection. The rock samples were gotten from fresh un-weathered surfaces in order to source for the un-altered fresh rock where the mineralogy of the rock has not been affected. The samples were stored in air tight sample bags and later taken to the laboratory to petrographic analysis. Tables 1-3 show the points of samples location.

\subsection{Soil Samples Analysis}

Heavy metals analyses were carried out using atomic absorption spectroscopy (AAS) after undergoing open total digestion where 2 grams of air-dried soil through ( $2 \mathrm{~mm}$ sieve) with foil paper was weighed accurately and transferred to 
Table 1. Soil sample locations from the study area.

\begin{tabular}{|c|c|c|c|c|}
\hline $\mathrm{S} / \mathrm{N}$ & LOCATION & SAMPLE CODE & LATITUDE & LONGITUDE \\
\hline 1 & EKPESHI & Soil 1 & $07^{\circ} 08^{\prime} 39.3 " \mathrm{~N}$ & $006^{\circ} 11^{\prime} 36.7^{\prime \prime} \mathrm{E}$ \\
\hline 2 & “ & Soil 2 & $07^{\circ} 08^{\prime} 33.2^{\prime \prime} \mathrm{N}$ & $006^{\circ} 11^{\prime} 42.2^{\prime \prime} \mathrm{E}$ \\
\hline 3 & “ & Soil 3 & $07^{\circ} 08^{\prime} 32.7^{\prime \prime} \mathrm{N}$ & $006^{\circ} 11^{\prime} 27.8^{\prime \prime E}$ \\
\hline 4 & “ & Soil 4 & $07^{\circ} 08^{\prime} 13.9^{\prime \prime} \mathrm{N}$ & $006^{\circ} 11^{\prime} 23.0^{\prime \prime} \mathrm{E}$ \\
\hline 5 & “ & Soil 5 & $07^{\circ} 10^{\prime} 15.8^{\prime \prime N}$ & $006^{\circ} 11^{\prime} 15.8^{\prime \prime} \mathrm{E}$ \\
\hline 6 & “ & Soil 6 & $07^{\circ} 10^{\prime} 52.4^{\prime \prime N}$ & $006^{\circ} 11^{\prime} 17.5^{\prime \prime E}$ \\
\hline 7 & “ & Soil 7 & $07^{\circ} 10^{\prime} 44.0^{\prime \prime} \mathrm{N}$ & $006^{\circ} 11^{\prime} 13.7^{\prime \prime} \mathrm{E}$ \\
\hline
\end{tabular}

Table 2. Water sample locations from the study area (Researcher Fieldwork, 2018).

\begin{tabular}{|c|c|c|c|}
\hline$S / N$ & SAMPLE CODE & CORDINATES & DESCRIPTION OF LOCATION \\
\hline 1 & EKW1 & $\begin{array}{l}07^{\circ} 08^{\prime} 43.2^{\prime \prime N} \\
006^{\circ} 11^{\prime} 16.7^{\prime \prime} \mathrm{E}\end{array}$ & Stream \\
\hline 2 & EKW2 & $\begin{array}{c}07^{\circ} 08^{\prime} 33.3^{\prime \prime N} \\
006^{\circ} 11^{\prime} 50.7^{\prime \prime} \mathrm{E}\end{array}$ & Stream \\
\hline 3 & EKW3 & $\begin{array}{l}07^{\circ} 08^{\prime} 33.0^{\prime \prime} \mathrm{N} \\
006^{\circ} 11^{\prime} 28.0^{\prime \prime} \mathrm{E}\end{array}$ & Tap Water \\
\hline 4 & EKW4 & $\begin{array}{c}07^{\circ} 08^{\prime} 13.9^{\prime \prime} \mathrm{N} \\
006^{\circ} 11^{\prime} 23.0^{\prime \prime} \mathrm{E}\end{array}$ & Tap Water \\
\hline 5 & EKW5 & $\begin{array}{c}07^{\circ} 08^{\prime} 16.2^{\prime \prime} \mathrm{N} \\
006^{\circ} 11^{\prime} 24.0^{\prime \prime} \mathrm{E}\end{array}$ & Tap head \\
\hline 6 & EKW6 & $\begin{array}{l}07^{\circ} 10^{\prime} 15.2^{\prime \prime} \mathrm{N} \\
006^{\circ} 11^{\prime} 15.9^{\prime \prime} \mathrm{E}\end{array}$ & Stream \\
\hline 7 & EKW7 & $\begin{array}{c}07^{\circ} 09^{\prime} 51.7^{\prime \prime} \mathrm{N} \\
006^{\circ} 11^{\prime} 17.8^{\prime \prime} \mathrm{E}\end{array}$ & Stream \\
\hline 8 & IGW1 & $\begin{array}{c}07^{\circ} 16^{\prime} 27.8^{\prime \prime} \mathrm{N} \\
006^{\circ} 06^{\prime} 18.4^{\prime \prime} \mathrm{E}\end{array}$ & Hand-Dug well \\
\hline 9 & IGW2 & $\begin{array}{c}07^{\circ} 16^{\prime} 30.6^{\prime \prime} \mathrm{N} \\
006^{\circ} 06^{\prime} 24.5^{\prime \prime} \mathrm{E}\end{array}$ & Hand-Dug well \\
\hline 10 & IGW3 & $\begin{array}{l}07^{\circ} 16^{\prime} 35.2^{\prime \prime} \mathrm{N} \\
006^{\circ} 06^{\prime} 45.6^{\prime \prime} \mathrm{E}\end{array}$ & Hand-Dug well \\
\hline
\end{tabular}

Table 3. Rock sample locations from the study area.

\begin{tabular}{cccc}
\hline S/N & SAMPLE CODE & LATITUDE & LONGITUDE \\
\hline 1 & Rock S1 & $07^{\circ} 08^{\prime} 40.8^{\prime \prime N}$ & $006^{\circ} 11^{\prime} 37.0^{\prime \prime} \mathrm{E}$ \\
2 & Rock S2 & $07^{\circ} 10^{\prime} 16.3^{\prime \prime} \mathrm{N}$ & $006^{\circ} 11^{\prime} 16.0^{\prime \prime} \mathrm{E}$ \\
3 & Rock S3 & $07^{\circ} 10^{\prime} 52.7^{\prime \prime N}$ & $006^{\circ} 11^{\prime} 17.2^{\prime \prime} \mathrm{E}$ \\
4 & Rock S4 & $07^{\circ} 10^{\prime} 44.2^{\prime \prime} \mathrm{N}$ & $006^{\circ} 11^{\prime} 13.4^{\prime \prime} \mathrm{E}$ \\
\hline
\end{tabular}


$250 \mathrm{ml}$ beaker. A measured volume of well-mixed acid, nitric acid and hydrochloric acid in the ratio 1:3 respectively was transferred into the beaker containing the soil sample in the fume hood. It was heated to about fifteen to twenty minutes on the hot plate until white fumes were observed emanating from the beaker containing the soil sample. Then, the digestion is stopped and allowed to cool. After cooling, $20 \mathrm{ml}$ of distilled water was added and boiled gently to bring the metal into solution. The content of the beaker was further allowed to cool and filtered through Whatman 42 filter paper in a $50 \mathrm{ml}$ volumetric flask and made to mark with distilled water, then the content was transferred into a clean plastic container for AAS analysis. The determination of the total content of Co, $\mathrm{Ni}, \mathrm{Cu}, \mathrm{Zn}, \mathrm{Cd}$ and $\mathrm{Pb}$ was done using the flame atomic absorption spectrometer.

\subsection{Water Samples Analysis}

Apart from the $\mathrm{pH}$, temperature, conductivity, and TDS measurement that was done in-situ, all other analyses were done using the flame atomic absorption spectrometric method. Heavy metals analyses were carried out using the atomic absorption spectroscopy (AAS) before which $250 \mathrm{ml}$ sample was measured into a beaker and $5 \mathrm{ml}$ Nitric Acid $\left(\mathrm{HNO}_{3}\right)$ is added. The solution was evaporated to near dryness on a hot plate, making sure that the sample does not boil. The beaker was allowed to cool and another $5 \mathrm{ml}$ of Conc. $\mathrm{HNO}_{3}$ added. The beaker is covered with a watch glass and returned to the hot plate. A gentle refluxing action of the solution is set by increasing the temperature of the hot plate. Heating will continue with addition of acid as necessary until digestion is completed (light colored residue obtained). $1.2 \mathrm{ml}$ Conc. $\mathrm{HNO}_{3}$ was added to dissolve the residue. The residue is then washed with distilled water and filtered to remove silicate and other insoluble materials. The volume of the solution was adjusted to $100 \mathrm{ml}$ in a volumetric flask. A reagent blank determination was carried out, samples and reagent blank were analyzed for total heavy metals with the flame AAS. The determination of the total content of $\mathrm{Co}, \mathrm{Ni}, \mathrm{Cu}, \mathrm{Zn}, \mathrm{Cd}$ and $\mathrm{Pb}$ was done using the flame atomic absorption spectrometer.

\subsection{Rock Samples Analysis}

The rock samples were subjected to petrographic analysis adopting [11] method where a thin section of $30 \mu \mathrm{m}(0.03 \mathrm{~mm})$ thick slice of rock is attached to a glass slide with epoxy. The petrographic slides were viewed under a petrographic microscope to determine the mineralogical composition of the rocks.

\section{Results of the Sample Analyses}

\subsection{Petrographic Results}

The microscopic analysis performed on the thin section slides using a petrography microscope, both polarizing and cross polarized lights reveals the major rock forming minerals in the rock. The photomicrographs of the samples are shown in Figure 3. Where "A" denotes view under Cross-polarized light (XP) 


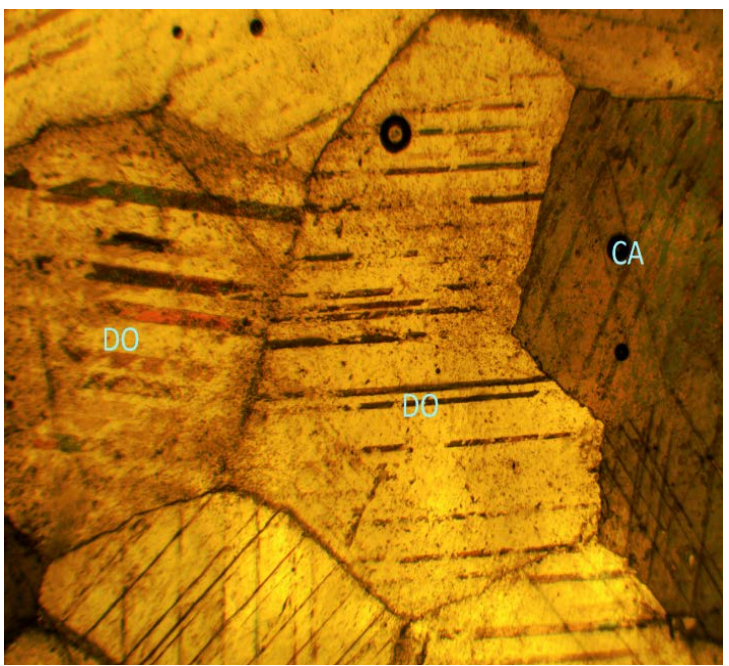

(a)

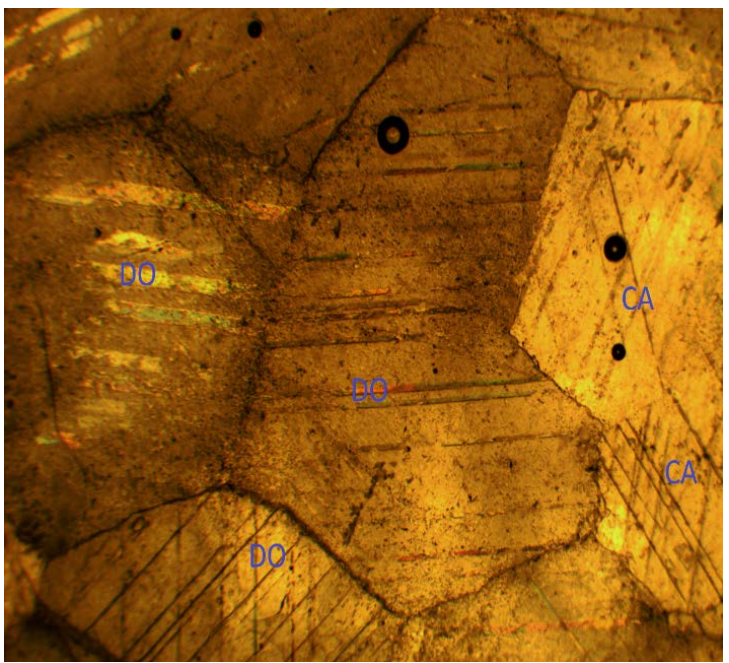

(b)

Figure 3. Photomicrograph of Low-Grade Dolomitic marble $(\times 40)((\mathrm{a})=\mathrm{XP}$; $(\mathrm{b})=\mathrm{PPL})$ $\mathrm{DO}=$ Dolomite, $\mathrm{CA}=$ Calcite .

with magnification of $(\times 40)$ of both eye piece and lens and " $B$ " denote viewed under Plane-polarized light $(\mathrm{PPL})$ with magnification $(\times 40)$ eye piece and lens.

\subsection{Geochemistry Results (Water and Soil)}

The result of the concentration of elements on seven (7) soil samples taken from seven different locations is presented in Table 4 . And this data is plotted as histogram as shown in Figure 4.

The results for the concentration of elements in water samples are presented in Table 5. Mean concentrations of the elements and other parameters ( $\mathrm{pH}, \mathrm{EC}$, TDS, \& Temperature) of the results obtained from the ten samples are compared with the guideline on drinking water standard of [12] and [13] for assessing the water quality in the study area. The comparison shows that $\mathrm{Pb}, \mathrm{Cd}$, and $\mathrm{Cu}$ in most of the areas are above the permissible limits of both [12] and [13]. 


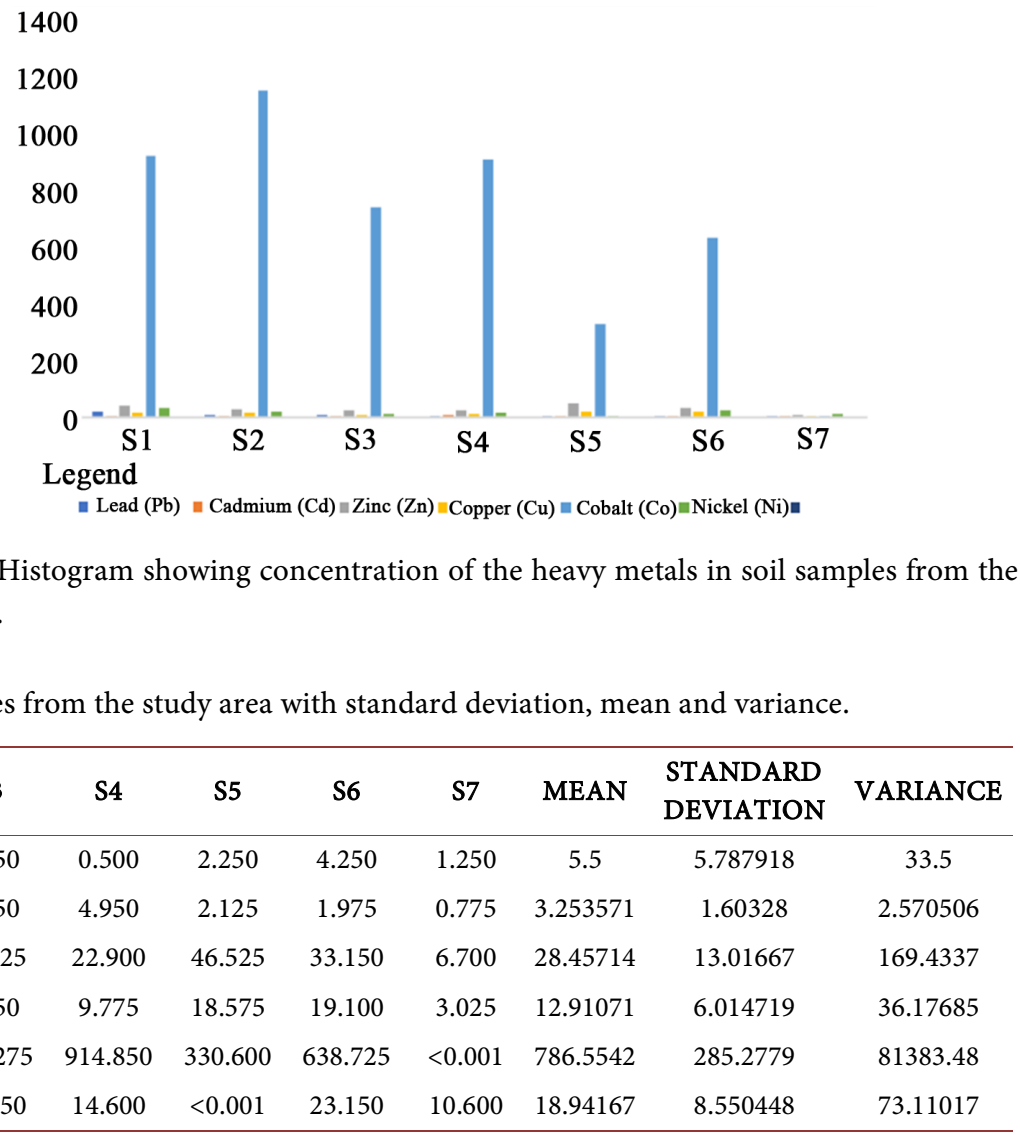

Table 4. Heavy metals concentration in soil samples from the study area with standard deviation, mean and variance.

\begin{tabular}{cccccccccccc}
\hline Parameters & Unit & S1 & S2 & S3 & S4 & S5 & S6 & S7 & MEAN & $\begin{array}{c}\text { STANDARD } \\
\text { DEVIATION }\end{array}$ \\
\hline Lead $(\mathrm{Pb})$ & $\mathrm{mg} / \mathrm{kg}$ & 17.500 & 6.000 & 6.750 & 0.500 & 2.250 & 4.250 & 1.250 & 5.5 & 5.787918 & 33.5 \\
Cadmium $(\mathrm{Cd})$ & $\mathrm{mg} / \mathrm{kg}$ & 4.575 & 4.225 & 4.150 & 4.950 & 2.125 & 1.975 & 0.775 & 3.253571 & 1.60328 & 2.570506 \\
Zinc $(\mathrm{Zn})$ & $\mathrm{mg} / \mathrm{kg}$ & 39.525 & 28.375 & 22.025 & 22.900 & 46.525 & 33.150 & 6.700 & 28.45714 & 13.01667 & 169.4337 \\
Copper $(\mathrm{Cu})$ & $\mathrm{mg} / \mathrm{kg}$ & 14.800 & 16.750 & 8.350 & 9.775 & 18.575 & 19.100 & 3.025 & 12.91071 & 6.014719 & 36.17685 \\
Cobalt $(\mathrm{Co})$ & $\mathrm{mg} / \mathrm{kg}$ & 928.450 & 1159.425 & 747.275 & 914.850 & 330.600 & 638.725 & $<0.001$ & 786.5542 & 285.2779 & 81383.48 \\
Nickel $(\mathrm{Ni})$ & $\mathrm{mg} / \mathrm{kg}$ & 33.725 & 19.025 & 12.550 & 14.600 & $<0.001$ & 23.150 & 10.600 & 18.94167 & 8.550448 & 73.11017 \\
\hline
\end{tabular}

Table 5. Comparison of the results with [12] and [13] Guideline for drinking water standards including standard deviation, variance and mean concentration of the samples.

\begin{tabular}{|c|c|c|c|c|c|c|c|c|c|c|}
\hline & $\mathrm{Pb}(\mathrm{mg} / \mathrm{l})$ & $\mathrm{Cd}(\mathrm{mg} / \mathrm{l})$ & $\mathrm{Zn}(\mathrm{mg} / \mathrm{l})$ & $\mathrm{Cu}(\mathrm{mg} / \mathrm{l})$ & $\mathrm{Ni}(\mathrm{mg} / \mathrm{l})$ & Co $(\mathrm{mg} / \mathrm{l})$ & $\mathrm{pH}$ & EC & TDS (ppm) & Temp $\left({ }^{\circ} \mathrm{C}\right)$ \\
\hline NIS & & & & & & & & & & \\
\hline $\begin{array}{c}\text { STANDARD } \\
(2007)\end{array}$ & 0.01 & 0.003 & 3.0 & 1.0 & 0.02 & - & $6.5-8.5$ & 1000 & 500 & Ambient \\
\hline WHO & & & & & & & & & & \\
\hline $\begin{array}{c}\text { STANDARD } \\
(2012)\end{array}$ & 0.01 & 0.003 & 3.0 & 2.0 & 0.07 & - & $6.5-9.2$ & 500 & 500 & - \\
\hline EKW1 & 0.800 & 0.235 & 0.265 & 2.845 & 0.620 & $<0.001$ & 8.1 & 243 & 122 & 25.2 \\
\hline EKW2 & 1.550 & 0.165 & 0.170 & 0.050 & 0.345 & 15.225 & 9.2 & 483 & 242 & 27.0 \\
\hline EKW3 & $<0.001$ & 0.080 & 0.820 & $<0.001$ & $<0.001$ & $<0.001$ & 8.9 & 393 & 196 & 26.6 \\
\hline EKW4 & 0.300 & 0.190 & 0.325 & $<0.001$ & 0.015 & $<0.001$ & 9.5 & 248 & 125 & 32.0 \\
\hline EKW5 & 0.050 & 0.085 & 2.355 & 0.200 & $<0.001$ & $<0.001$ & 8.0 & 152 & 300 & 31.0 \\
\hline EKW6 & 0.200 & 0.130 & 0.585 & 0.010 & $<0.001$ & $<0.001$ & 9.3 & 329 & 163 & 28.8 \\
\hline EKW7 & 0.350 & 0.160 & 0.635 & 0.135 & 0.230 & $<0.001$ & 8.9 & 325 & 162 & 28.6. \\
\hline IGW1 & $<0.001$ & 0.055 & 0.870 & 0.010 & $<0.001$ & $<0.001$ & 9.3 & 134 & 230 & 31.0 \\
\hline IGW2 & $<0.001$ & 0.045 & 0.655 & $<0.001$ & 0.170 & $<0.001$ & 8.4 & 358 & 179 & 27.9 \\
\hline IGW3 & 0.150 & 0.015 & $<0.001$ & $<0.001$ & $<0.001$ & $<0.001$ & 9.4 & 583 & 289 & 27.9 \\
\hline MEAN & 0.485714 & 0.116 & 0.742222 & 0.541667 & 0.276 & 15.225 & 8.9 & 320.3 & 200.8 & 28.6 \\
\hline $\begin{array}{l}\text { STANDARD } \\
\text { DEVIATION }\end{array}$ & 0.527347 & 0.071016 & 0.651585 & 1.130888 & 0.226147 & & 0.549747 & 134.9502 & 62.85574 & 2.165897 \\
\hline VARIANCE & 0.278095 & 0.005043 & 0.424563 & 1.278907 & 0.051143 & & 0.302222 & 18211.57 & 3950.844 & 4.691111 \\
\hline
\end{tabular}




\section{Discussion}

\subsection{Petrography}

Microscopic analysis shows that the marble consists of equi-granular granoblast calcite which shows interlocking grain boundaries. Petrographic analysis of the thin sections of the rock samples observed under both plane and cross polarized light petrographic microscope shows that the framework minerals that make up the calcite and dolomitic marble to include dolomite, calcite and some amount of feldspar minerals. Calcite occurs as the most dominant mineral in the calcitic marble while dolomite occurs as the dominant mineral in the dolomitic marble. No other minerals were recognizable under the microscope. The calcite crystals and the dolomite crystals display triple point boundaries. Calcite minerals in the samples occur as equi-granular crystals, most of them showing perfect rhombohedra cleavage and twinning. The carbonate phase of these marbles is more commonly whitish to greyish white in color. Under thin-section microscope observation, the general impression is that the analyzed marble present disequilibrium geometries due to contact metamorphism characterized by relatively high temperature and low pressure [14], which caused predominantly quick re-crystallization of the carbonate phases leading to the formation of fine-grained crystals in the rock.

\subsection{Soil Geochemistry}

Worldwide soil standards are hardly seen because the geology of areas differs from each other. The elemental analyses carried out on Soil samples $1-7$, shows a wide a range of values and these values will be correlated with the Dutch Standard for soil value. The concentration of $\mathrm{Pb}, \mathrm{Cd}, \mathrm{Zn}, \mathrm{Cu}, \mathrm{Co}$, and $\mathrm{Ni}$ of soil samples are given in Table 5. The standard permissible limit for soil value used to compare the results of the analyses is given below in Table 6 .

The concentration of Cadmium in the soil samples from the various sampled points range from 0.775 to $4.950 \mathrm{mg} / \mathrm{kg}$ (Table 4). The permissible limit of cadmium in soil recommended by the [16], is $0.8 \mathrm{mg} / \mathrm{kg}$ (Table 6) and results for samples Soil-1 to Soil- 6 obtained are above the permissible limit with values

Table 6. Standard permissible limit for soil value.

\begin{tabular}{cc}
\hline Elements & *Target value of soil $(\mathbf{m g} / \mathbf{k g})$ \\
\hline $\mathrm{Pb}$ & 85 \\
$\mathrm{Cd}$ & 0.8 \\
$\mathrm{Zn}$ & 50 \\
$\mathrm{Cu}$ & 36 \\
$\mathrm{Co}$ & - \\
$\mathrm{Ni}$ & 35 \\
\hline
\end{tabular}

${ }^{\star}$ Target values are specified to indicate maximum levels of elements in unpolluted soils (Source: [15] and $[16])$. 
ranging from 1.975 to $4.950 \mathrm{mg} / \mathrm{kg}$. The high concentration of $\mathrm{Cd}$ in the soil could be associated to marble mining and milling activities in the area due to the mineral excavation, rock transportation, processing of the rocks in this area and disposal of the waste and waste water around the mine [17]. In a related study [18] reported that $\mathrm{Pb}$ is released to the environment (water) due to Baryte Mining in Azara are of Nasarwa State, Nigeria which is associated with trace elements like As, Cd and Sb, could be compared with results from [19] that these trace elements are linked to mineralization not strictly due to mining. Also, [18] observed that most of the abandoned mining paddocks/pits have served as death traps to humans and livestocks in the Azara area, which is a clear reflection of our current studies in the Igarra Marble mining area. Not limited to that, land degradation associated to marble mining in this area affects the community resilience with the direction and response rate becoming complex [20].

The concentration of Copper $(\mathrm{Cu})$ in the soil ranged from 3.025 to 19.100 $\mathrm{mg} / \mathrm{kg}$ (Table 4), which is below the concentration of Dutch Standard $36 \mathrm{mg} / \mathrm{kg}$. Copper is a micro element which is essential in plant growth and occurs generally in soil [21] sediments and air. $\mathrm{Cu}$ content has been reported to differ according to the soil type and pollution source [22].

The concentration of Nickel (Ni) in the soil samples is 0.001 to $33.735 \mathrm{mg} / \mathrm{kg}$. Recommended limit for Ni by Dutch Standard 1994 is $35 \mathrm{mg} / \mathrm{kg}$. The samples were below this recommended limit and could be considered that plants are safe from risk of Nickel effects. Nickel has been an essential trace element for human and animal health [23]. The concentration of Lead $(\mathrm{Pb})$ in the soil samples from the study area is $0.500-17.500 \mathrm{mg} / \mathrm{kg}$. The Dutch standard limit of Lead is 85 $\mathrm{mg} / \mathrm{kg}$, results for the soil were low and did not exceed the recommended limits. Lead poisoning, especially in young children, is a global environmental and public health hazard [24]. These results suggest that the study area is safe from $\mathrm{Pb}$ poisoning.

In this study, the concentration of Zinc ( $\mathrm{Zn}$ ) varies widely from 6.700 to $46.525 \mathrm{mg} / \mathrm{kg}$ (Table 4 and Figure 4), and the recommended limit by Dutch Standard 1994 is $50 \mathrm{mg} / \mathrm{kg}$. All values have low concentration compared to its permissible limit. The concentration may be because of the number of trucks that quarry the marble fragments and their emissions at the mining site and milling factories. $\mathrm{Zn}$ deficiencies tend to occur on calcareous (high $\mathrm{pH}$ ) soils that are associated with calcareous rocks such as marble [25]. Zn deficiency may result in substantial losses in crop yields and human nutritional health problems.

The value of the concentration of Cobalt (Co) from the study area is 0.001 to $928.450 \mathrm{mg} / \mathrm{kg}$ and it has no recommended limit by the Dutch Standard. The toxicity of cobalt is quite low compared to many other metals in soil. It is essential for the growth and development of certain animals. The soils near mines and milling factories contain very high amounts of cobalt, so that the uptake by humans eating via transfer from crops (e.g. corn, cassava, vegetables, and tomatoes) may lead to health problems such as vision, nausea and vomiting, and heart diseases. Although, Cobalt is also beneficial for humans because it is a part 
of vitamin $B_{12}$, which is essential for human health.

According [21], they found out that along heavy traffic roads in Kwara State, North Central Nigeria, concentration of $\mathrm{Pb}$ in soil samples was between 24 to $142 \mathrm{mg} / \mathrm{kg}$, cadmium was BDL (below detection limit) to $0.366 \mathrm{mg} / \mathrm{kg}$, copper between 7.70 to $80.13 \mathrm{mg} / \mathrm{kg}$, and zinc between 30.8 to $219.23 \mathrm{mg} / \mathrm{kg}$ respectively, and they all exceeded the permissible limit set the Dutch standard for soil, which is a potential signal of pollution to the environment.

Considering the high concentration of $\mathrm{Ni}, \mathrm{Pb}, \mathrm{Zn}$ in both water and soil samples and because of the near neutral $\mathrm{pH}$ condition of the water regimes and the moisture conditions plus other factors, soluble iron-sulfate minerals or rock forming minerals may precipitate during dry periods relative to saturated and unsaturated zones leading to accumulation of dissolved species because of evaporation [26]. Similarly, this situation is comparable to [26] where they reported trace element distribution are control by adsorption, surface complexation and co-precipitation that gave rise to heavy metal attenuation.

In a related study [27] showed that waste heaps from mining activities had led to the pollution of soils, lakes, rivers and coastal areas which has been observed in both local and regional impacts on terrestrials and aquatic ecosystem. The current investigation has proved a similar impact at a local level, and we suggest that advance mitigation plan should be put in place to limit the extend of potential havoc mining and processing of Marble might cause to the surrounding environment of Igarrah.

\subsection{Water Geochemistry}

Results from water samples EKW1, EKW2, EKW3, EKW4, EKW5, EKW6, EKW7, IGW1 IGW2 and IGW3 in the study area shows a wide a range of values as presented in Figure 5 .

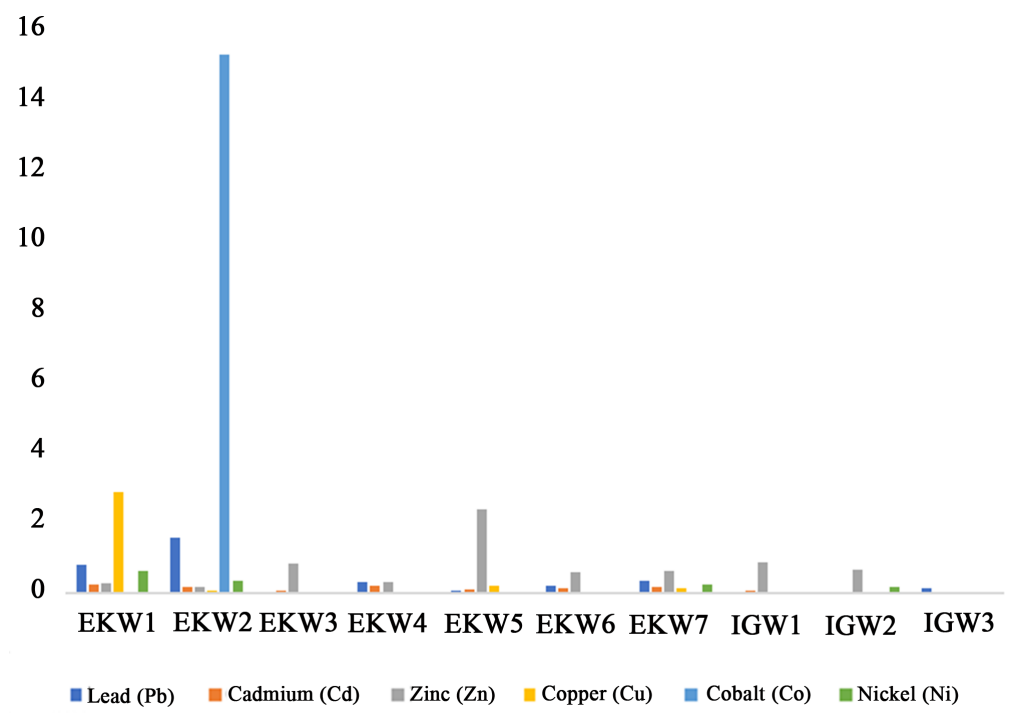

Figure 5. Histogram showing the distribution of the heavy metals in water samples from the study area. 
The resultant concentration of these elements, this could be linked or associated with the mineralogical and chemical composition of the rocks within the study area being marble with high percentage of calcite as evidence from the thin sections (Figure 3 \& Figure 4). Although, it has no direct impact on consumers, it is one of the most important operational water quality parameters.

Zinc $(\mathrm{Zn})$ is observed to be the dominant heavy metal (Table 5), with concentration range of 0.001 to $2.355 \mathrm{mg} / \mathrm{l}$ and mean value of 0.742222 . Zinc imparts an undesirable astringent taste to water at a taste threshold concentration of about $4 \mathrm{mg} / \mathrm{l}$ (as zinc sulfate). Water containing zinc at concentrations more than 3 to $5 \mathrm{mg} / \mathrm{l}$ may appear opalescent and develop a greasy film on boiling, although drinking-water seldom contains zinc at concentrations above $0.1 \mathrm{mg} / \mathrm{l}$.

The concentration of Copper $(\mathrm{Cu})$ was 0.001 to $2.845 \mathrm{mg} / \mathrm{kg}$ (Table 5), which most of the samples apart from sample EKW1 mean value of $2.845 \mathrm{mg} / \mathrm{kg}$.

The concentration of Cobalt (Co) in the water samples from the study area also varied widely between 0.001 to $15.225 \mathrm{mg} / \mathrm{kg}$ with sample EKW2 been the highest at $15.225 \mathrm{mg} / \mathrm{kg}$. The concentration of Nickel (Ni) in water sample from the study area varies from 0.001 to $0.620 \mathrm{mg} / \mathrm{kg}$ (Table 5). All the samples show low concentrations except for samples EKW1-0.620 mg/kg, EKW2-0.345 mg/kg, EKW7-0.230 mg/kg, and IGW2-0.170 mg/kg.

The concentration of Lead $(\mathrm{Pb})$ in the water samples from the study area is in the range of 0.001 to $1.550 \mathrm{mg} / \mathrm{kg}$. The current result is high and presents a potential risk to the environment, because [19] have highlighted the effect of $\mathrm{Pb}-\mathrm{Zn}$ on water bodies in the middle Benue Trough Nigeria.

The concentration of Cadmium (Cd) in water samples from the study area showed concentration of 0.015 to $4.950 \mathrm{mg} / \mathrm{kg}$ Table 5 . The high concentration of $\mathrm{Cd}$ in the water samples may be associated to marble mining and milling activities carried out in the area, because of the presence of quartz veins which forms favorable zone for the occurrence of hydrothermal deposits are rich in $\mathrm{Pb}$. Absorption of cadmium compounds is dependent on the solubility of the compounds. Cadmium accumulates primarily in the kidneys and it is very toxic to the kidney when in high concentrations.

\section{Conclusions}

Analysis carried out on soil and water samples from the Marble mining district of Igarra and Ekpeshi shows that the following heavy metals $\mathrm{Pb}, \mathrm{Cd}, \mathrm{Zn}, \mathrm{Ni}, \mathrm{Cu}$, and Co, have concentrations above the permissible limits for the guidelines for drinking water standard of [12] and [13] have varying effects/impacts on human health and the environment, which are associated with mining of marble in the area and natural input from the continuous weathering of the rocks.

This study is the first of its kind to be conducted in the Igarra mining district and presents as preliminary investigation on assessment environmental impact/effect of marble mining with emphasis on monitoring groundwater quality and soil, to evaluate the impact it has on the cultivation of crops and plants. The study has shown that the mining activities in the area have considerable effects 
on the people living around the mines and milling factories from the comparison between the concentration of heavy metals in the water around the mining area and the soil in the area with [13] standard and [12] standard for portable drinking water, and [16].

The high values of Lead and Cadmium in the water samples from the various processes lifted above may be of serious concern to the health of the people leaving around the mining district if actions such as water treatment are not taken to reduce the level of these metal concentration in the water around this mines and milling factories, as it contributes to the high level of surface and groundwater contamination. The soil samples Soil-1 to Soil-7 that were collected in Ekpeshi are observed to have high concentration of Cadmium. The concentration of cadmium is associated with the mining of the marble rock and milling processes of the marble in the area.

Other environmental effects of the mining activities in the area include noise from drilling and/or blasting of the rock formation, sound of generating sets, powering of the plants and the daily movement of entry of heavy-duty vehicles into/out of the sites and the milling activities, dust in the air causing air pollution from the milling factories which were all observed during the mining operations. The dust particulates from the milling factories is demonstrated by thick deposits of white powder on the roofs of the houses, leaves of plants and crops, thus reducing the level of photosynthesis making the plants cover to change from green to yellow or other colors and this affects and impact on the yields of the plants and crops. Invariably, it has negative impact on the annual yield of crops from the farms.

\section{Recommendation}

To maintain a sustainable mining of Marble in Igarra and Ekpeshi mining district, it is highly recommended that all the exploration and exploitation stages involve in its extraction, be conducted in line with [28] and as provided in the [28]. This would be in line with the millennium development goals (Goal 7), and sustainable development goals i.e. (Goal 9) towards for vision 2030. There should be adequate control of dust and fumes from the processing mills in order to curb the level of dust been release to the atmosphere by keeping the area wet all the time and all the waters used has to be treated before discharging it into the drainage system to minimize the concentration of the heavy metal been carried into the drainage system via mobility of these anions and cations in different medium. This is would be in line with the recommendation given by [29], on the concentration of dissolved tantalum seawater and freshwaters which are present in particulate from in natural waters. Also, it recommended that use of water sources around the mining areas for drinking should be treated through either boiling, filtration and chlorination and as part of corporate social responsibility the companies operating in the area should be made to drill water boreholes for the communities and provide advocacy/sensitization visit these areas 
and how to curb with it the difficulties, alternatively.

\section{Conflicts of Interest}

The authors declare no conflicts of interest regarding the publication of this paper.

\section{References}

[1] Nabalek, P.I. (1991) Stable Isotope Monitors. Reviews in Mineralogy, 31, 89-97.

[2] Jimoh, O.A., Elueze, A.A. and Ahmed, J.B. (2014) Geochemistry and Economic Potential of Marble from Obajana, North Central, Nigeria. Pelagia Research Library, 5, 146-151.

[3] Saliu, M.A. and Komolafe, K. (2014) Investigating the Effect of Dolomite Exploitation on Groundwater Condition of Ikpeshi, Akoko-Edo, Edo State, Nigeria. Journal of Earth Sciences and Geotechnical Engineering, 4, 137-147.

[4] Aigbedion, I.N. and Iyayi, S.E. (2007) Environmental Effect of Mineral Exploration in Nigeria. International Journal of Physical Sciences, 2, 33-38.

[5] Soheila, K.Y. and Bahram, S. (2011) The Environmental Effect of Mine. International Journal of Energy and Environment, 5, 495-502.

[6] Eludoyin, O.M., Adeleke, I.O., Webster, R. and Eludoyin, A.O. (2014) Air Temperature, Relative Humidity, Climate Regionalization and Thermal Comfort of Nigeria. International Journal of Climatology, 34, 2000-2018.

https://doi.org/10.1002/joc.3817

[7] Nigerian Meteorological Agency (2018) Seasonal Rainfall Report and Prediction Report, 2018.

https://fscluster.org/nigeria/document/nigerian-meteorological-agency-nimet

[8] Ileoje, N.P. (2001) A New Geography of Nigeria, New Revised Edition. Longman Publishers, Ibadan, 200.

[9] Odeyemi, I.B. (1976) Preliminary Report on the Field Relationship of the Basement Complex around Igarra, Midwest Nigeria. In: Kogbe, C.A., Ed., Geology of Nigeria, Elizabethan Press, Lagos, 365-369.

[10] Agomuo, M.S. and Egesi, N. (2016) Petrology and Structural Geology of Ikpeshi and Its Environs of Igarra Schist Belt, Southwestern Nigeria. International Journal of Science Inventions Today, 5, 303-319.

[11] Adepoju, M.O. and Adekoya, J.A. (2011) Reconnaissance Geochemical Study of Part of Igarra Schist Belt, South Western Nigeria. Ife Journal of Science, 13, 75-92.

[12] WHO (2012) Guideline for Drinking Water.

[13] NIS (2007) Nigerian Standard for Drinking Water Quality. 554.

[14] Franzini, M., Lezzerini, M. and Origlia, F. (2010) Marbles from the Campiglia Marittima Area (Tuscany, Italy). European Journal of Mineralogy, 22, 881-893. https://doi.org/10.1127/0935-1221/2010/0022-2056

[15] Denneman, C.A. and Robberse, J.G. (1990) Ecotoxicological Risk Assessment as a Base for Development of Soil Quality Criteria. In: Contaminated SoiP90, Springer, Dordrecht, 157-164. https://doi.org/10.1007/978-94-011-3270-1_28

[16] Ministry of Housing Netherlands (1994) Dutch Intervention Values for Soil Remediation (Report HQ 94-021). Environmental Quality Objectives in the Netherlands, Ministry of Housing, The Hague. 
[17] Salomons, W. (1995) Environmental Impact of Metals Derived from Minerals Activities: Processes, Predictions, Prevention. Journal of Geochemical Exploration, 25, 125-132. https://doi.org/10.1016/0375-6742(94)00039-E

[18] Chaanda, M.S., Obaje, N.G., Moumouni, A., Goki, N.G. and Lar, U.A. (2010) Environmental Impact of Artesinal Mining of Baryte in Azara Area, Middle Benue Trough, Nigeria. Journal of Earth Sciences, 4, 38-42. https://doi.org/10.3923/ojesci.2010.38.42

[19] Lar, U.A. and Sallau, A.K. (2005) Trace Elements Geochemistry of the Keana Brines Filed Middle Benue Trough, Nigeria. Environmental Geochemistry and Health, 27, 331-339. https://doi.org/10.1007/s10653-004-5736-7

[20] Blake, W.H., Rabinovich, A., Wynants, M., Kelly, C., Nasseri, M., Ngondya, I., Patrick, A. and Navas, A. (2018) Soil Erosion in East Africa: An Interdisciplinary Approach to Realising Pastoral Land Management Change. Environmental Research Letters, 13, Article ID: 124014. https://doi.org/10.1088/1748-9326/aaea8b

[21] Ogundele, D.T., Adio, A.A. and Oludele, O.E. (2015) Heavy Metal Concentrations in Plants and Soil along Heavy Traffic Roads in North Central Nigeria. Journal of Environmental and Analytical Toxicology, 5, 334.

[22] Onder, S., Dursun, S., Gezgin, S. and Demirbas (2007) Determination of Heavy Metals Pollution in Grass and Soil of City Centre Green Area (Konya, Turkey). Poland Journal of Environment Studies, 1, 145-154.

[23] Hjorkenkrans, D. (2003) Diffuse Metal Emission to Air from Road Traffic. A Case Study of Kalmer, Sweden. Environmental Science Section Bulletin, 1-55.

[24] Adriano, D.C. (2001) Arsenic. In: Trace Elements in Terrestrial Environments, Springer, New York, 219-261. https://doi.org/10.1007/978-0-387-21510-5_7

[25] McGregor, R.G., Blowes, D.W., Jambor, J.L. and Robertson, W.D. (1998) Mobilization and Attenuation of Heavy Metals within a Nickel Mine Tailings Impoundment near Sudbury, Ontario, Canada. Environmental Geology, 36, 305-319. https://doi.org/10.1007/s002540050346

[26] Bigham, J.M. and Kirk Nordstrom, D. (2000) Iron and Aluminum Hydroxysulfates from Acid Sulfate Waters. Reviews in Mineralogy and Geochemistry, 40, 351-403. https://doi.org/10.2138/rmg.2000.40.7

[27] Allan, R.J. (1995) Impact of Mining Activities on the Terrestrial and Aquatic Environment with Emphasis on Mitigation and Remedial Measures. In: Förstner, U., Salomons, W. and Mader, P., Eds., Heavy Metals, Environmental Science, Springer, Berlin, Heidelberg, 119-140. https://doi.org/10.1007/978-3-642-79316-5_8

[28] Nigerian Mining and Mineral Act (2007) Enacted by the National Assembly of the Federal Republic of Nigeria. Act No. 20.

[29] Filela, M. (2017) Tantalum in the Environment. Earth-Science Reviews, 173, 122-140. https://doi.org/10.1016/j.earscirev.2017.07.002 